\title{
PENDIDIKAN AKHLAK PADA ANAK TUNALARAS DI SEKOLAH LUAR BIASA PRAYUWANA YOGYAKARTA
}

\author{
La Ode Yarfin ${ }^{1}$, Suyadi ${ }^{2}$ \\ ${ }^{1}$ Program Studi Pendidikan Agama Islam, Universitas Ahmad Dahlan' \\ ${ }^{2}$ Program Studi Magister Pendidikan Agama Islam Program Pascasarjana Universitas Ahmad \\ Dahlan \\ Email: suyadi@fai.uad.ac.id HP; 085241808971
}

\begin{abstract}
Islamic religious education is a right for all children, including children with special needs, especially disability or disorder of social disorders and deviant behavior. These conditions require a new approach in Islamic religious education, thus forming a noble. The purpose of this study was to analyze the moral education of children with physical impairment in E Prayuwana Special School (SLB) Yogyakarta. This research approach is qualitative in the form of descriptive analysis. The subjects of this study were 4 children with grades 2, 3, 4 and 5 Elementary / SLB and one Teacher of Islamic Education. Data collection techniques carried out by observation, interviews and documentation. Data analysis was performed in a descriptive and analytical way. The results showed that moral education in children with physical impairment was done by conditioning good manners, worship habits, and honest behavior.
\end{abstract}

Keywords: Islamic education, tunalaras, habituation, and honesty.

\begin{abstract}
Abstrak
Pendidikan agama Islam merupakan hak bagi semua anak, termasuk anak berkebutuhan khusus, terlebih lagi tunalaras atau gangguan kelainan sosial dan perilaku menyimpang. Kondisi tersebut menuntut pendekatan baru dalam pendidikan agama Islam untuk mengubahnya menjadi berakhlak mulia. Tujuan penelitian ini adalah menganalisis pendidikan akhlak pada anak tunalaras di Sekolah Luar Biasa (SLB) E Prayuwana Yogyakarta. Pendekatan penelitian ini adalah kualitatif deskriptif.Subyek penelitian ini adalah 4 anak tunalaras kelas 2, 3, 4 dan 5 Sekolah Dasar/ SLB dan satu Guru Pendidikan Agama Islam. Teknik pengumpulan data dilakukan dengan observasi, wawancara dan dokumentasi. Analisis data dilakukan secarcara deskriptif dan analitis. Hasil penelitian menunjukkan bahwa pendidikan akhlak pada anak tunalaras dilakukan dengan pengkondisian sopan santun, pembiasaan beribadah, dan perilaku jujur. Anak tunalaras memiliki kecenderungn untuk meniru perilaku negatif, sehingga perlu stimulasi akhlak terpuji yang jauh lebih besar dari pada pengaruh negatif di lingkungan sekitarnya.
\end{abstract}

Kata Kunci: pendidikan Islam, tunalaras, pembiasaan, dan kejujuran. 


\section{PENDAHULUAN}

Pendidikan merupakan salah satu tujuan mengubah pola pikir sesorang dalam mencapai keberhasilan (Suyadi, 2018b). Pendidikan berkenan dengan perkembangan dan perubahan kelakuan anak didik (Ratnasari, 2014). Pendidikan bertalian dengan transmisi pengetahuan, sikap, kepercayaan, keterampilan dan aspek-aspek kelakuan lainya kepada peserta didik. Pendidikan akhlak juga mempunyai peran yang sangat penting dalam kehidupan manusia agar menjadi pribadi yang baik dan terarah pada jalan yang benar. Agama menjadi pemandu dalam upaya mewujudkan suatu kehidupan yang bermakna dalam bermanfaat. Dengan menyadari betapa pentingnya peran pendidikan Akhlak bagi kehidupan manusia yang lebih khususnya anak-anak yang berkelakuan kurang baik, penanaman nilai-nilai akhlak dalam kehidupan setiap pribadi menjadi keharusan atau kewajiban yang harus ditempuh melalui pendidikan, baik itu pendidikan di lingkungan keluarga, masyarakat maupun lingkungan sekolah.

Anak-anak yang berkatagori tunalaras adalah anak yang berklainan gangguan perilaku yang dimana gangguan tersebut bisa menimbulkan gangguan-gangguan terhadap sekitarnya atau hambatan emosi dan tingkah laku tidak sesuai dengan lingkunganya (Suyadi, 2017). Sekolah luar biasa berkatagori $\mathrm{E}$ ini merupakan sekolah anak yang berkebutuhan khusus dengan katagori ketunalarasaan, dan ada juga anak-anak yang lain salah satunya anak bekebutuhan tunagraeta, autis dengan berbagai katagori tingkatan yang bermacam-macam. Adapun setiap kelas itu hanya beberapa anak yang di ajarkan oleh guru ada satu kelas hanya 2 anak dan ada juga 3,/4 anak di bandingan sekolah pada umumnya. Setiap guru menangani Cuma beberapa anak yang berkebutuhan khusus.

Pendidikan adalah merupakan bimbingan secara sadar oleh pendidik terhadap perkembangan jasmani dan ruhani terdidik menuju terbentuknya keperbadian yang utama.Layanan pendidikan bagi anak berkebutuhan khusus sebagaimana yang suda diamanatkan dalam dalam Undang-Undang Nomor 20 Tahun 2003 tentang system pendidikan Nasional menyatakan bahwa "Warga Negara yang memiliki kelainan fsik, emosional, mental, intelektual, dan atau social berhak memperoleh pendidikan khusus (Hidayat, 2017).Dalam Islam, pendidikan inklusi bagi anak berkebutuhan khusus (ABK) menjadi salah satu perhatian dalam penyelenggaraan pendidikan. Allah SWT berfirman dalam Surat 'Abasa ayat 1-4.

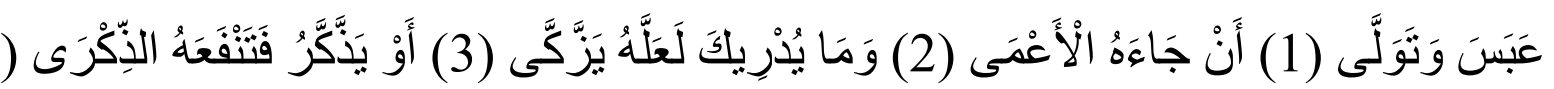

Artinya: Dia bermuka masam dan berpaling. Karena telah datang seorang tuna netra kepadanya. Tahukah kamu barangkali ia ingin membersihkan dirinya (dari dosa). Atau 
Dia (ingin) mendapatkan pengajaran, lalu pengajaran itu memberi manfaat kepadanya? (Q.S. 'Abasa [80]: 1-4)( Al-Qur'an 80)

Ayat menandakan setiap manusia berhak mendapatkan pendidikan baik yang normal maupun abnormal. Maka dari itu pendidikan merupakan salah satu tujuan dalam mencapai nilainilai kebaikan dalam membentuk perilaku yang baik dalam kehidupan bersosial. Kata akhlak berasal dari bahasa Arab, yaitu isim mashdar dari kata akhlaqo, yakhluk, akhlaaqon yang berarti “budi pekerti, adat kebiasaan, perangi, muru'ah atau segalah sesuatu yang sudah menjadi tabi'at.( Ratnasari 2016). Adapun makna akhlak Ibnu Qoyyim mendefinisikan sebagai perilaku yang dihasilkan dari sumber ilmu yang benar, kehendak yang baik/suci, dan dari amalan-amalan yang lahir maupun batin serta perkataan yang benar sesuai dengan asas kadilan, hikmah, dan maslahat, yang menimbulkan perbuatan-perbuatan yang lahir dari dalam jiwa.( Mahmudi 2018). Karena itu, pendidikan akhlak terhadap anak, menjadi fokus utama dalam Islam. Hala tersebut dijelaskan oleh Rasulullah:

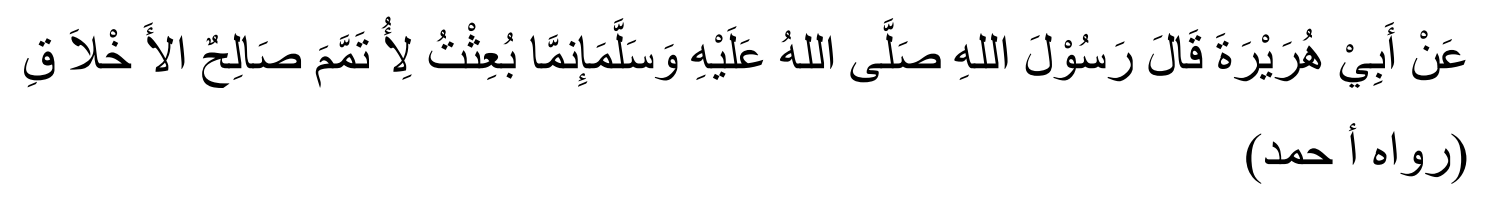

Dari Abi Hurairah berkata, Rasulullah bersabda: "Sesungguhnya saya diutus tidak lain hanyalah untuk menyempurnakan akhlak.” (HR. Imam Ahmad)

Pendidikan akhlak terhadap anak sangat penting. Karena yang paling penting, sekaligus merupakan masa yang sangat berbahaya. Jika tidak dididik atau diperhatikan secara benar oleh orang tua, maka nantinya anak tumbuh dalam keadaan akhlak yang kurang baik (Zamroni, 2017).

Seorang anak ibarat kertas putih, apabila kertas itu ditulis dengan tinta warna merah, maka kertas menjadi merah, apabila kertas ditulis warna hijau, maka kertas menjadi hijau. Semua bergantung pada pola pendidikan yang diberikan oleh orang tua kepada anaknya. Anak tunalaras dalam pekembangan emosinya mengalami gangguan sehingga dalam bertingkah laku mereka cenderung melanggar norma-norma sosial, agama dan hukum yang berlaku di lingkungannya. Hal ini kadang merugikan dirinya sendiri, orang lain dan bahkan merugikan dari segi pendidikannya.

Pendidikan untuk anak tunalaras harus dirancang sedemikian rupa, sehingga program dan layanannya berjalan sesuai dengan lingkungan anak tunalaras. Seperti anak tunanetra, tunarunggu, tunagraita, dan lain-lainnya. Ketidak mampuandalam berinteraksi dengan masyarakta di sekitanya. Dengan gangguan perilaku emosi dan perilaku sehingga perlunya pendidikan akhlak pada anak tunalaras dengan strategi untuk membiasakan anak tersebut menjadi orang-orang berakhlak mulia sesuai dengan ajaran Islam. 


\section{Pendidikan akhlak}

Dalam memahami makna dari kata pendidikan, maka perlu di jelaskan beberapa definisi pendidikan secara umum dan terpisah, hal ini dimaksudkan agar bias difahami definisi pendidikan dan akhlak. Pendidikan adalah menciptakan berbagai perubahan pada berbagai dimensi keberadaan manusia dan perilaku, dengan tujuan mengarahkanya pada suatu sasaran yang merupakan hal penting dan menentukan nasib seseorang segalah bentuk pebaikan dan pembinaan individu maupun masyarakat, pastilah melalui pendidikan (Muali, 2015).

Dalam sisitem pendidikan Nasional pendidikan diartikan sebagai usaha sadar dan terencana untuk mewujudkan suasana belajar dan proses pembelajaran agar peserta didik secara aktif mengembangkan potensi dirinya untuk memiliki kekuatan spiritual keagamaan pengendalian diri, kepribadian, kecerdasan, akhlak mulia, serta ketarampilan, yang diperlukan dirinya, masyarakat, bangsa, dan Negara.(Bandung: Fokus Media, 2009) Sebagaimana akhlak menurut Hamzah Ya'qub berasal dari bahasa Arab, jamak Dari kata "khuluqun”, artinya tindakan. Kata “khuluqun” sepadan dengan kata "khalqun”, kejadian dan kata "khuluqun”, Artinya pencipta dan kata “makhluqun”, yang diciptakan. Adapun yang dimaksud akhlak adalah keadaan jiwa yang menetap dan dari padanya terbit semua perbuatan dengan muda tanpa memerlukan pemikiran dan penelitian. Bilah terbit dari jiwaperbuatan-perbuatan baik dan terpuji berate ia akhlak baik dan sebaliknya jika perbuatan tidak baik maka itu perbuatan akhlak buruk. Menurut Zakiah Daradjat, macam-macam akhlak terhadap Allah diantarnya:

a. Taat terhadap perintah-perintah Nya

b. Memiliki rasa tanggung jawab atas amanah yang diembankan padanya.

c. Senantiasa bertaubat kepada-Nya

d. Obsensinya adalah keridhaan ilahi

e. Meralisasikan ibadah kepada-Nya.

f. Banyak membaca al Qur'an.(chusnul 2018)

Akhlak kepada manusia menurut Rahman Ritonga, diantaranya adalah akhlak terhadap diri sendiri, akhlak terhadap orang tua, akhlak betetangga, dan akhlak terhadap guru (Chusnul, 2018).

Akhlak yang baik dengan sesama manusia perlu dijaga agar tidak ada orang yang merasa bahwa hak dan harga dirinya terlanggar oleh orang lain. Manusia, statusnya dalam masyarakat tetap mempunyai harga diri, yang menjadi milik dan karunia Allah kepadanya.

\section{Anak tunalaras}

Tunalaras adalah istilah yang digunakan untuk anak yang berkelainan perilaku atau anak yang mengalami gangguan/hambatan emosi dan tingkahlaku sehingga tidak/kurang menyesuaikan diri dengan baik, baik terhadap lingkungan keluarga, sekolah, maupun masyarakat (Efendi 2008) 
Anak yang diidentifikasi mengalami gangguan atau kelainan perilaku adalah anak yang: a) tidak mampu mendefinisikan secara tepat kesehatan mental dan perilaku yang normal, b) tidak mampu mengukur emosi dan perilakunya sendiri, dan c) mengalami kesulitan dalam menjalankan fungsi sosialisasi.

Mendefinisikan gangguan anak tunalaras atau gangguan emosi dan perilaku menurut Hallahan dan kauffman dapat di mulai dari tiga ciri khas kondisi emosi dan perilaku, yakni: (1) tingkah laku yang sangat eksrim dan hukan hanya berbeda dengan tingkah laku anak lainnya, (2) suatu problem emosi dan perilaku yang kronis, yang tidak muncul secara langsung, (3) tingkah laku yang tidak diharapkan oleh lingkungan karena bertentangan dengan harapan sosial dan kultural. Sebagaimana tampak dalam peristilahnnya, anak tunalaras atau gangguan emosi diuraikan sebagai kesulitan dalam penyesuaian diri dan tingkah laku yang tidak sesuai dengan norma-norma yang berlaku dalam lingkungan kelompok usia maupun masyarakat pada umummnya, sehingga merugikan dirinya maupun orang lain.

Adapun dari beberapa pendapat para ahli dapat di simpulkan bahwa anak tunalaras merupakan anak yang memiliki gangguan emosional maupun degan gangguan perilaku terhadap lingkungan seusianya maupun sosial atau lingkungan masyarakta pada umumnya. Dapat dikatakan mengalami gangguan perilaku apabilah memiliki satu atau lebih dari lima karakteristik berikut dalam kurun waktu yang lama, yaitu:

a. Ketidakmampuan untuk belajar yang bukan disebabkan oleh faktor intelektualitas, alat indra maupun kesehatan.

b. Ketidakmampuan untuk membangun atau memelihara kepuasan dalam menjalin hubungan dengan teman sebaya dan pendidik.

c. Tipe perilaku yang tidak sesuai atau perasaan yang di bawaah keadaan norma.

d. Mudah terbawa suasana hati (emosi labil), ketidakbahagiaan, atau depresi.

e. Kecendrungan untukmengembangkan simpatom-simpatom fisik atau ketakutan-ketakutan yang diasosiasikan dengan permasalahan-permasalahan pribadi atau sekolah.

Simptom gangguan emosi dan perilaku biasanya dibagi menjadi dua macam, yaitu externalizing behavior dan internalizing behavior. E xternalizing behavior memiliki dampak Adapun dari beberapa pendapat para ahli dapat di simpulkan bahwa anak tunalaras merupakan anak yang memiliki gangguan emosional maupun degan gangguan perilaku terhadap lingkungan seusianya maupun sosial atau lingkungan masyarakta pada umumnya. 


\section{METODE}

Pendekatan penelitian ini adalah kualitatif jenis deskriptif kualitatif. Metode penelitian kualitatif merupakan salah satu jenis penelitian yang spesifikasinya sistimatis, terencana, dan terstruktur sejak awal hingga akhir penelitian. Taylor mendefinisikan penelitian kualitatif sebagai penelitian yang menghasilkan data deskriptif berupa kata tulis atau lisan dari orang atau perilaku yang dapat di amati (Djaman, 2014).

Sugiono metode penelitian kualitatif merupakan metode penelitian yang berlandaskan pada filsafat post positivisme, digunakan untuk meneliti pada kondisi objek alamiah,(sebagai lawanya adalah eksperimen) dimana peneliti adalah sebagai instumen kunci, pengambilan sample sumber data dilakukan secara purposive dan snowball, teknik penggunaan dengan triangulasi (gabungan), analisis data bersifat induktif/kualitatif, dan hasil penelitian kualitatif lebih menekan "makna" dari pada generalisasi (Sugiono 2014).Untuk mengetahui pendidikan akhlak pada anak tunalaras di SLB E Prayuwana Yogyakarta.

\begin{tabular}{ll}
\hline \multicolumn{1}{c}{ Pendekatan } & Kualitatif \\
\hline \multirow{3}{*}{ Teknik pengumpulan data } & Observasi \\
& Wawancara \\
& Dokumentasi \\
\hline & Penelitiansebagai intrumen kunci \\
& Mengunakan instumen terstruktur yaitu berupa \\
& pertanyaan-pertanya yang sudah di buat oleh \\
peneliti & Mengunakan rekaman HP, alat tulis dan dll. \\
\hline & Deskriptif pengambilan sample sumber data \\
& dilakukan secara purposivedan snowball, teknik \\
& penggunaan dengan trigulasi(gabungan) analisis \\
& datanya bersifat induktif / kualitatif. \\
& Pengambilan datanya langsung di lapangan \\
& Subjek yang diteliti yaitu 4 orang anak tunalaras \\
& dan satu orang guru PAI di SLB E Prayuwana \\
& Yogyakarta \\
& Objek yang diteliti yaitu berupa pendidikan akhlak \\
& pada anak tunalaras di SLB E Prayuwana \\
& Yogyakarta \\
\hline \multirow{3}{*}{ Analisis data } &
\end{tabular}

\section{HASIL DAN PEMBAHASAN}

\section{A. Pendidikan akhlak pada anak tunalaras di SLB E Prayuwana}

Pendidikan Akhlak adalah pembiasaan seorang anak untuk berakhlak baik dan berperangi luhur seningga hal ini menjadi pembawaanya yang tetap dan sifatnya yang senantiasa 
menyertainya (Ibrahim, 2015). Termasuk dalam pendidikan akhlak adalah menjaukan anak dari akhlak yang tercela dan perangi yang buruk seorang anak akan tumbuh sesuai dengan kebiasaan yang tanamkan oleh sang pendidik terhadapnya. Tentang ini Ibn al- Qayyim rahimahullah berkata:

"Termasuk sesuatu yang sangat dibutukan oleh anak kecil adalah perhatian terhadap perkara akhlaknya. Karena, ia akan tumbuh sesuai dengan apa yang dibiasakan oleh pendidikan dimasa kecilnya (Ibrahim, 2015).

Begitu juga dengan SLB E Prayuwana Yogyakarta yang sangat menjunjug dalam mewujudkan pendidikan akhlak terhadap anak tunalaras sesuai dengan ajaran Islam. Melalui guru agma Islam sebagai edukator dalam meningkatkan pendidikan akhlak pada anak seperti melakukan pembiasan sopan santun, pembiasaan berprilaku, pembiasaan kejujuran, pembiasaan akhlak dalam pembelajaran dalam kelas, pembiasaan akhlak di luar kelas. Sebagaimana yang jelaskan bapak Trianto, S. HI tentang gambaran umum pendidikan akhlak pada anak tunalaras di SLB E Prayuwana Yogyakarta beliau merupakan salah satu informasi dalam penelitian ini yang menyatakan bahwa :"Karena sesungguhnya pembiasaan pendidikan akhlak itu sendiri, perubahan dalam bersopan santun dan perubahan akhlak pada anak tunalaras itu sendiri yang tadinya harapannya setelah dididik dan dibina SLB E Prayuwana ini bisa berubah karakternya, berubah akhlaknya menjadi bertingkah laku yang baik (Trianto, 2019). Adapun pembahasan pendidkan akhlak pada anak tunalaras berdasrkan hasil observasi dan wawancara yang dilakukan oleh peneliti sebagai berikut :

1. Kondisi akhlak Anak tunalaras di SLB E Prayuwana Yogyakarta

Perlaku anak tunalaras di SLB E secara umum adalah: suka mencuri, gangguan emosional, menekan atau menyakiti, menarik diri, mengeluarkan kata-kata tidak benar (provokator) dan berbicara jorok, dan tidak sopan termasuk kepada guru yang merupakan orang lebih tua darinya (Trianto, 2019). "Pemicu munculnya sifat dan akhlak yang kurang baik misalnya bicara kotor, kemudian susah diatur, kemudian merusak karna ada keinginan dia yang kurang baik. Maka akhlak anak itu super ekstra yang luar biasa maka kita berusaha dan berupaya bagimana untuk mengendalikan anak(Trianto 2019).

Adapun menurut Tiara Rahayu perilaku moral anak secara umum yaitu, anak yang paling kuat akan berkuasa dengan menekan, memerintah, dan memukul yang lemah, perilaku tersebut merupakan perilaku yang paling menonjol, dan perilaku memprovokasi (Rahayu, 2016). Dari penjelasan di atas dapat dikatakan bahwa perilaku anak tunalaras di SLB E Prayuwana merupakan anak yang berkelainan tingkah laku, emosional, dalam perlaku kurang baik dalam bersosial dalam lingkunganya. 
2. Pembiasaan sopan santun

Pembiasaan merupakan salah satu metode pendidikan akhlak yang sangat penting, terutama bagi anak-anak. Mereka belum menginsafi apa yang disebut baik dan buruk dalam artis susila. Mereka juga belum mempunyai kewajiban-kewajiban yang harus dikerjakan seperti pada orang dewas, dan pola pikir tertentu. Anak perlu dibiasakan pada sesuatu yang baik (Mana, 2018).

Pada tanggal 20 Mei 2019 melakukan observasi bahwa peneliti melihat anak-anak tunalaras sangat kurang baik perilakunya terhadap teman-teman disekitarnya. Ketika gurunya melihat perilaku anka-anak tersebut maka guru langsung menasehatinya dengan cara memberitau bahwa memukul teman itu tidak baik, dan sesama teman harus saling menyangi dan membiasakan sopan santun kepada teman maupun gurunya. Maka dari situ peneliti tidak bisa melakukan kesimpilan bahwa mereka seperti itu. Dengan demikian Peneliti wawancara dengan kepala sekolah pada tanggal 30 agustus 2019:

"Pendidikan ahlaknya, karna akhlak sekolah SLB kami ini pertama bagaimana cara untuk lebih mereka bersopan santun kepada yg lebih tua, pada guru kemudian sesama teman sering berkelahi kemudian dengan lingkungan juga karna disini anak tunalaras mereka mengalami gangguan perilaku jadi terkadang ada jimpitan (barang) belum di ambil bahwa guru mengajarkan itu kepada anaknya bahwa barang itu jangan di ambil dan bagaimana cara meminta barang dengan sopan kapada anak. Jadi guru kelas banyak memberikan teori tetapi bagaimana mengajarkan kehidupan sehari hari." (Ernaningsi 2019).

Kemudian hasil wawancara dengan guru PAI yang dilakukan ruang kelas Pada tanggal 25 agustus 2019 sebagai berikut:

"Pembiasaan itu dengan kita tunjukan sifat dan akhlak yang baik seperti kita memperhatikan dia, menegur dengan lemah lembut, dengan kasih sayang. Harapannya dia akan merubah akhlak dia yang tadinya sudah tertanam dengan hal yan tidak baik itu, dan harapannya itu berubah menjadi lebih baik (Trianto 2019).

Sopan santun tatanan karma dalam kehidupan sehari-hari sebagai cerminan kepribadian dan budi pekerti luhur yang dalam Islam lebih dikenal dengan konsep akhlak (Trianto, 2019). dari beberapa pendapat diatas dapat dikatakn bahwa sopan santun merupakan tatanan akhlak yang akan terbentuk jika melalui suatu proses pengalaman, pendidikan, dan teladan yang baik dari kedua orang tua, guru maupun orang-orang di lingkunganya. Oleh karna itu pembiasaan akhlak dalam bersopan santu kepada orang tua, guru, bahkan di lingkungan sekitarnya merupakan suatu akhlak yang terpuji yang di ajarkan orang tua maupun guru itu sendiri. 
3. Pembiasaan perilaku

Perilaku baik merupakan cerminan dari akhlak terpuji disebut juga akhlak mahmudah. Berakhlak terpuji tidak hanya hubunganya dengan sesama manusia, tetapi juga terhadap Allah. Sebagai zat yang pencipta. Akhlak terpuji kepada Allah adalah suatu sikap atau perilaku terpuji yang hanya tujukan kepada Allah (Yanti, 2017). Pada tanggal 20 mei 2019 peneliti melakukan obervasi terhadap anak-anak tunalaras di SLB E Prayuwana bahwa anak tunalaras itu mereka masih sulit membedakan antara berbuat baik dengan berbuat buruk dan mereka terkadang cendurung bebuat buruk terhadap orang-orang disekitarnya. Adapun hasil dari wawancara dengan guru agama Islam tentang pembiasaan berbuat baik pada tanggal 25 agustus 2019 sebagai berikut:

"Pembiasaan-pembiasaan akhlak terhadap perilaku anak itu misalnya berprilaku kasih sayang, kemudian kerja sama, kemudian tolong menolong, saling menghargai, menjaga kebersihan. jadi seputaran bagaimana dia mengubah kerakternya selama ini itu ada dalam anak yang tidak baikpun kemudian lambat laun mudah-mudahan bisa lebih baik (Trianto, 2019).

Dari pendapat di atas dapat katakan bahwa pembiasan perilaku akhlak itu sejajar dengan apa yang anak lakukan, dengan demikian bisa dikatakan perilaku yang baik jika anak melakukan perbuatan baik di lingkungan sekitarnya.

4. Pembiasaan kejujuran

Kejujuran adalah suatu kesamaan antara yang dihati di ucapkan dan diperbuatan. Jujur keselarasan antara perkataan, perbuatan dan perasaan (fitriah 2017). Pada tanggal 20 mei 2019 peneliti melakukan observasi di sekolah SLB E Prayuwana Yogakarta terkait tentang kejujuran anak tunalaras ada beberapa anak yang menyembunyikan barang temanya mereka malah tidak mau jujur. Dari keterangan dari guru juga ketika anak itu lihat barang orang lain di jalan mereka ambil. Ketika gurunya nanya barang siapa itu, mereka ngga mau jawab dan ngga mau jujur. Berikut ini hasil wawancara dari guru agam Islam pada tanggal 25 agustus 2019 terkait pendidikan akhlak terkait penanamna kejujuran sebagai berikut:

“Jadi mas' anak-anak tunalaras terkadang masih suka berbohong jika melakukan kesalahan atau mengambil barang orang lain, terkadang membuat anak-anak berbohong karena takut dimarahi atau dihukum, padahal di SLB E Prayuwana ini tidak menerapkan metode hukuman. Jadi upaya yang saya lakukan adalah selalu memberi nasehat untuk berkata jujur kepada teman, guru dan orang tua, saat dikelas maupun diluar kelas (pak Trianto 2019). 
Dalam kejujuran dan keikhlasan sama sekali tidak ada kecendrungan untuk menyimpang. Melihat kondisi anak tunalaras tersebut memang tidak mudah untuk membiasakan mereka dalam berperilaku jujur.

5. Pembiasaan akhlak dalam kelas

Berkaitan penanaman akhlak anak dalam kelas memang bukan satu-satunya yang menetukan akhlak anak. Akan tetapi secara substansional mata pembelajaran pendidikan agama Islam memiliki konstribusi yang sangat besar terhadap penanaman akhlak anak. Karena guru sebagai penganti orangtua ketika anak berada di lingkungan sekolah maka seorang guru berkewajiban mendidik, membimbing dan mengarakan anak agar pendidikan agama tercapai ( St Daroja, 2006).

Pada tanggal 20 Mei 2019 peneliti melakukan observasi melihat kondisi pengajaran dalam kelasa memang berbeda dengan kelas-kelas sekolah pada umumnya dan anak tunalaras ketika mau memasuki kelas atau mau belajar itu harus di rayu dulu atau di datangi gurunya untuk masuk kelas dan untuk pembentukan akhlak anak di dalam kelas agak sulit ketimbang anak-anak pada umumnya. Berikut hasil wawancara dengan guru pendidikan agama Islam tentang penanaman akhlak dalam kelas pada tanggal 25 agustus 2019 di ruang kelas sebagai berikut:

"Kalau pembelajaran pendidikan agama Islam itu yang paling penting pembelajaran budi pekerti.Misalnya seperti shalat, puasa, dan materi-materi agama, bagimana penguasaan-penguasaan tentang dia itu hafal bacaan shalat.Kemudian bagaimana dia memahami tentang puasa.Mereka bisa menangkap dan mereka memahami bahwa misalnya seperti dulu saya memberikan sebuah pertanyaan kalau misalnya kalian menemukan uang di jalan kamu bakal ngapain dengan uang itu, mau di kembalikan atau di belikan jajan atau di serahkan di masjid Mereka tahu yang benar bahwasannya adalah di kembalikan. Tapi terkadang mereka jawabnya "tapikan aku yang dapat, jadi saya buat jajan sendiri (Trianto, 2019).

Dari hasil pendapat di atas dapat disimpulkan bahwa pembelajaran pendidikan agama Islam khususnya dalam penanaman akhlak merupakan salah satu bentuk, agar anak tunalaras mampu menerima pelajaran yang dismpaikan gurunya. Ada beberapa contoh materi atau pembelajaran yang diberikan guru di antaranya sholat, puasa, baca Qur'an, berdoa, cara berwuduh. agar proses pembentukan akhlak terhadap anak mampu mengapilkasikan dalam kehidupan sehari oleh anak itu sendiri.

6. Pembiasaan akhlak di luar kelas

Dalam pengertian sehari-hari, akhlak sering disamakan kata budi pekerti, moral atau etika. Moral perbuatan atau tindakan yang dilakukan sesuai dengan ide-ide atau pendapat yang umum diterima yang meliputi kesatuan sosial atau lingkungan-lingkungan tertentu. Etika ialah 
ilmu menyelediki mana yang baik dan buruk dengan memperhatikan amal perbuatan manusia seajauh yang dapat diketahui oleh akal pikiran (St Daroja, 2006).

"Biasanya kita ajak untuk keluar kelasa atau keluar sekolah atau ke masjid bahwa umat Islam itu ketika sholat di masjid guru memberikan pemahaman bahwa kewajiban sholat itu di masjid. untuk mengenalkan tempat wuduh dan kemudian masjid itu tempat sholat di ajarkan juga bagiman cara berwuduh. dan kita berikan pemahaman bahwa di masjid harus menjaga kesopanan, sehingga harapanya nanti ketika anak kembali kepada masyarakat atau di lingkunganya dia kemudia tidak meras minder dengan anak yang lain.Kalau untuk agama tentu di pelajaran dan akhlak, terus yang khusus kami kaitkan dengan kehidupan sehari-hari contonya mengajarkan etika atau moral yang untuk anak itu sendiri oleh guru kelasnya untuk anak tunalarasnya (Trianto 2019).

Pendidikan agama mengajarkan pentingnya penanaman akhlak yang dimulai dari kesadaran beragama pada anak. Ia mengajarkan akidah sebagai dasar keagamaanya, mengajarkan Al Qur'an dan hadist sebagai pedoman hidupnya, mengajarkan fiqih sebagai rambuh-rambuh hukum dalam beribadah, mengajarkan sejarah Islam sebuah keteladanan hidup, dan mengajarkan akhlak sebagai pedoman peilaku manusia apakah dalam katagori baik ataupun buruk (Aini, 2013)

\section{B. Faktor Pendukung dan Penghambat Pendidikan Akhlak pada anak tunalaras di SLB E Prayuwana Yogyakarta}

Berdasarkan hasil observasi dan wawancara penulis lakukan terdapat berapa faktor pendukung maupun faktor penghambat dalam proses pendidikan akhlak pada anak tunalaras melalui pembelajaran pendidikan agama Islampada anak tunalaras di SLB E Prayuwana Yogyakarta, yaitu sebagai berikut:

1. Faktor pendukung

Berikut adalah faktor pendukung dalam penjabaran pendidikan akhlak melalui PAI bagi anak tunalaras di SLB E PrayuwanaYogyakarta:

a. Jumalah peserta didik

Pada tanggal 20 mei 2019 melakukan observasi bahwa peneliti melihat kondisi siswa di SLB E Prayuwana sangat berbeda jau dengan sekolah pada umumnya. Di sekolah ini siswanya jumlanya sangat sedikit di bandingkan sekolah lain dan begitu juga di setiap kelas hanya beberapa anak yang masuk dan yang lain tidak masuk atau tidak datang sekolah adapun pembelajaran PAI sendiri dalam satu kelas itu ada beberapa siswa yang masuk. Berikut hasil wawancara dengan pak Trianto pada tanggal 25 agustus 2019 sebagai berikut:

"Jumlah peserta didik di SLB E Prayuwana Yogyakarta setiap kali pembelajaran PAI maksimal ada 4 siswa, tetapi pak Trianto lebih sering mengajar 2 siswa dalam setiap kelasnya (Trianto, 2019). 
Pelayanan individual dalam rangka mendidik anak berkelainan perlu Hal tersebut dikarenakan jumlah siswa yang tidak banyak serta hanya beberapa siswa yang aktif berangkat sekolah. Selain itu pembelajaran dengan siswa lebih dari 2 anak dipantau secara terus menerus. Menurut pak Trianto selaku pengampu mata pelajaran PAI di SLB E Prayuwana, jumlah siswa yang sedikit akan mempermuda guru untuk mengondisikan kelas.

Dari hasil wawancara yang penulis lakukan dengan pak Trianto, beliau mangaku terkadang masih kewalahan mengondisikan 2 siswa dalam setiap kelasnya ketika mereka sedang berulah (Trianto, 2019). Jadi, dapat dikatakan bahwa jumlah siswa yang sedikit menjadi keuntungan tersendiri bagi guru karena perhatian guru dalam mengoodiner kelas akan lebih fokus dan juga siswa lebih mudah diawasi serta pendekatan secara individual dapat dilakukan sehingga guru dapat membing anak-anak satu demi satu.

b. Sikap guru di sekolah

Peran guru sangat penting dalam keberhasilan pelaksanaan kegiatan belajar mengajar. Guru adalah sosok yang dicontoh apa-apa yang dilakukan oleh gurunya, entah itu sikap atau perilaku baik atu tercelah. Guru-guru di SLB E Prayuwana memberikan contohcontoh yang baik terutama guru PAI. Sikap perilaku terpuji yang dilakukan seperti tidak berkata kasar, sabar, membiasakan mengucap salam, dan menyapa.

"Bimbingan kita dengan sikap lemah lembut, karena anak cenderung mencontoh, meniru, mengamati, jika anak mengikuti sikap kita, mencontoh sikap kita, anak itu sebenarnya merekam, mungkin suatu saat akan diputar rekaman tersebut (Trianto, 2019).

Dari potongan pendapat tersebut diketahui bahwa tanpa kita sadari anak merekam kejadian-kejadian yang dialaminya. Guru harus mencontokan sikap-sikap yang baik terhadap anak dan Suatu saat bukan tidak mungkin anak menampakan kejadian-kejadian yang pernah ia lakukan dalam perilakunya. Oleh karena itu pak Trianto selaku guru PAI selalu berusaha menamilkan sikap dan akhlak yang baik didepan anak-anak didiknya.

c. Sikap anak

Sikap adalah sebagai suatu kesiapan mental atau emosional dalam dalam beberapa jenis tindakan pada suatu yang tepat (Minarsi, 2016). Anak yang memiliki kemauan untuk belajar bisa mengalami peningkatan yang lebih cepat dari anak tidak mau mengikuti pelajaran sama sekali (Suyadi, 2016). Terkadang anak malas untuk belajar gara-gara keterbelakangan mereka dan kondisi mentalnya. 
d. Keluarga

Keberadaan orang tua sangat penting dalam perkembangan anak (Suyadi dan Maulidya Ulfa, 2013). Dukungan orang terdekat anak akan mempercepat perubahan sikap kearah yang lebih baik (Suyadi, 2018a). Pada tanggal 25 agustus 2019 peneliti melakukan wawancara kepada pak trianto seperti berikut:

"Dukungan tersebut berupa komunikasi yang baik antara anak dan orang tua serta keluarga, perhatian orang tua kepada anak sangat dibutukan, tidak terlalu memanjakan anak, tidak berkata kasar kepada anak, memberikan contoh yang baik didepan anak, kerjasama yang baik antara orang tua denga sekolah ( Trianto, 2019).

Dengan adanya komunikasih yang baik kerjasama baik antara pihak sekolah dan pihak orang tua atau keluarga siswa, pendidikan akhlak anak akan lebih mudah dan cepat, selain itu akan terjadi singkron apa yang diajarkan disekolah dan apa yang diterima di rumah, bukan malah sebaliknya (Yusmaliana \& Suyadi, 2019).

e. Media belajar

Media belajar adalah hal wajib ada dalam pembelajaran (Suyadi Suyadi, 2018b). Salah satunya karakter anak tunalaras adalah membangkang, susah diatur dan semuanya sendiri. Guru dituntut selalu kratif dan selalu punya invoasi sehingga ketika anak merasa bosan, guru punya sesuatu yang baru dancukup menarik untuk menarik perhatian anak sehingga mereka mau belajar (Suyadi, 2013).

Media yang bervariasi sangat diperlukan demi menujang pembelajaran. Seperti yang terjadi di SLB E ini pak Trianto selaku guru agama selalu berinovasi dengan media yang digunakan, mulai dari audio visual seperti gadget, leptop dengan video-video yang tentu saja mendukung materi yang sedang disampaikan. Selain media audio visual pak Trianto juga menggunakan media lingkungan, anak diajak untuk ke masjid untuk mengatasi rasa jenuh anak. Kegiatan pembelajaran yang dilakukan diluar sekolah tersebut tentu saja melibatkan banyak guru kelas. Berikut adalah contoh kegiatan akhir pada rencana pelaksanaan pembelajaran PAI di SLB E Prayuwana Yogyakarta: 
Kegiatan Akhir (10 menit)

Menonton film yang terkait kisah nabi dan diakhiri dengan berdo'a.

\begin{tabular}{lll}
\hline Langkah - langkah & Waktu & \multicolumn{1}{c}{ Deskipsi } \\
\hline & & $\begin{array}{l}\text { Menonton film yang } \\
\text { terkait kisah nabi dan } \\
\text { diakihiri dengan berdo'a }\end{array}$ \\
Langkah -1 & $10.30-10.40$ & \\
\hline
\end{tabular}

Dengan adanya media audio visual diproyeksikan dengan infokus / LCD Projector, guru langsung bisa memberikan bukti kongkrit atas apa yang sedang diajarkan dengan harapan anak bisa melihat, membandingan, memhami, mengingat dan membuktikan atas apa yang telah disampaikan guru kepadanya (Hayati 2017). Adapun dari pendapat di atas dapat dikatakan bahwa media audio visual dapat membantu guru dalam pengembangan pembelajaran dalam kelasa. Dalam potongan rencana pelaksanaan pembelajaran tersebut terlihat bahwa pak Trianto menggunakan media audio visual adalah yang, berupa film terkait materi pembelajaran.

2. Faktor penghambat

a. Sikap anak

Sikap anak yang mau belajar dan mengikuti pelajaran menjadi faktor yang mendukung perkembangan akhlak, hanya saja tidak semua anak yang memiliki kemauan tersebut. Banyak anak yang datang sekolah bukan karena kemauan sendiri bahkan terpaksa masuk sekolah (Suyadi, 2019). Akhirnya ketika pembelajaran mereka tidak mengikuti pelajaran dengan baik, mereka selalalu membuat keributan atau berulah agar tidak terjadi proses belajar mengajar (Putro. \& Suyadi, 2016). Hal tersebut bisa dikarenakan suasana hati anak yang sedang tidak baik karena ada masalah. Anak yang datang sekolah dengan suasana hati kurang baik tentu saja akan mengangu pelajaranya. Anak tidak mau ikut belajar bahkan anak tidak mau masuk kelas. Mayoritas anak tunalaras memang kesulitan mengontrol emosinya dan cendrung moody, seperti dalam kasus di atas anak yang tidak mau mengikuti pelajaran karena sedang tidak ingin belajar atau malas untuk belajar. Berbeda dengan anak normal yang mungkin ketika malas tetap masih mau mengikuti pelajaran meskipun dengan malasmalasan. 
b. Teman sekolah

Teman adalah faktor yang sangat mempengaruhi dalam perkembangan akhlak anak. Pada tanggal 25 agustus 2019 peneliti melakukan wawancara kepada pak trianto selaku guru pendidikan agama Islam di antaranya sebagai berikut:

“Anak yang awalnya tidak bermasalah ketika sudah beinteraksi dengan anak yang memiliki maslah celfin menjadi anak yang bermasalah juga, misalnya anak awalnya masuk sekolah tidak bermasalah dengan kata-kata kotor dan seru tapi karena temantemanya sering mengucapkan kata-kata kotor dan saru akhirnya si anak ikut-ikutan. Faktor penghambat lagi yaitu interaksi antar teman, misalnya anak yang satunya tidak ada masalah tapi ketemu dengan anak yang bermasalah entah itu maslah dirumah, maslah disekolah, maslah hp, maslah makanan, jadi tadi anak yang tidak maslah bertemu dengan anak yang punya maslah jadi punya maslah. Awalnya guru memangil anak untuk masuk kelas untuk mengikuti pembelajaran dikelas akan tetapi anak tidak mau masuk kelas malahan anak tersebut pergi tingalkan gurunya. Bakan anak yang lainya melakukan keributan dan saling mangangu dalam kelas (Trianto, 2019)

Dari pendapat di atas dapat dikatakan bahwa teman yang beperilaku baik akan berpengaruh terhadap teman yang lainya begitu juga sebaliknya teman yang buruk akan menjadi hambatan terhadap teman yang lainnya juga. Tetapi berbeda dengan anak tunalaras yang di bandingan dengan anak-anak normal dengan tingkah laku yang berbeda. Anak tidak mau belajar bahkan tidak mau masuk kelas karena mereka malas dan tidak ada temanya yang berangkat sekolah. Hal ini cukup sering terjadi apalagi kondisi lagi hujan. Hal tersebut wajar terjadi di kalangan anak-anak SLB E Prayuwana, berbeda dengan anak normal mereka akan tetap berangkat sekolah dan mengikuti pelajaran. Dalam kasus tersebut anak tidak bisa menyesuaikan diri, dalam hal ini yaitu tetap mengikuti pelajaran sebagaimana mestinya, serta tidak mampu memahami bahwa apabila ia keluar masuk di kelas lain akan manggangu proses pembelajaran.

c. Keluarga

Keluarga atau orang tua yang mendukung anak akan menjadi faktor pendukung, namun orang tua yang mengabaikan anak akan menjadi faktor menghambat perkembangan akhlak anak. Pada tanggal 25 agustu 2019 peneliti melakukan wawancara sama pak trianto sebagai berikut:

"Sikap orang tua, dan kata-kata yang diucapkan atau dilontarkan akan orang tua akan mempengaruhi anak. Anak akan meniru apa-apa yang dilakukan oran tua (Trianto, 2019)

Dukungan orang tua juga dapat berupa komunikasi yang baik antara orang tua dengan pihak sekolah. Dengan komunikasih dan kerja sama yang baik antara orang tua dan sekolah akan mempermudah pembentukan akhlak anak. Sebaliknya apabilah orang tua cuek dan 
tidak peduli dengan sekolah anak perubahan perilaku ke arah yang lebih baik akan lebih lambat dan sedikit terhambat.

d. Media /gedged

Kemudian teknologi tidak hanya memiliki dampak positif terhadap perkembangan akhlak anak tetapi juga memiliki danpak negatif (Wulandari \& Suyadi, 2019). Adanya gedged dengan teknologi yang canggih akan memudakan anak untuk mengakses apa saja (Saifurrahman \& Suyadi, 2019). Tidak banyak anak yang mangakses hal-hal yang tidak sepantasnya diakses. Seperti yang didengar penulis dari salah satu anak SLB E Prayuwana bahwa mereka mengaku melihat video sex di youtube. Anak yang dibiarkan mangakses gedged tnpa didampingi oran tua akan sangat berbahaya bagi perkembangan akhlak anak. Di era ini sangat menyesalkan orang tua membiarkan anak yang masih umur 2 atau 4 tahun sudah dikenalkan dengan gedget sehingga otak akan rusak apabilah melihat video-video tidak sepantasnya dilihat oleh anak.

\section{KESIMPULAN}

Pendidikan akhlak pada anak tunalaras di SLB E prayuwana Yogyakarta adalah bagaimana pendidikan agama Islam memberikan sumbangsih terhadap akhlak anak dengan adanya pembiasaan akhlak, pembiasaan sopan santun, pembiasaan kejujuran kepada anak akan bertransformasi dalam perilaku yang baik dengan di terapkanya nilai-nilai akhlak pada anak. Adapun faktor-faktor pendukung dan penghambat di SLB E prayuwana adalah merupakan salah satu penunjang bagi anak dalam pembentukan akhlak anak diantaranya guru, teman,orang tua dan teknologi akan sangat terpengaruh dalam pembentukan anak yang baik atau yang kurang baik.

\section{DAFTAR PUSTAKA}

Aini Mahabbati, "Pendidikan Inklusi untuk Anak dengan gangguan emosi dan Perilaku(tunalaras)",Pendidikan Khusus Vol.7 no. 2, (UNY”, FIP Pendidikan Luar Biasa, 2010), 54

Ajat Sudrajat, hubungan antara pola asuh orang tua dan ketaatan beribadah dengan perilaku sopan santun peserta didik. Pendidikan IPS volume 2,(PPS”,Univeritas Negri Yogyakarta, 2015), 192.

Al-Qur'an (surah Abasa [80]: 1-4)

Amin Zamroni, strategi pendidikan akhlak anak,vol. 12,( SAWWA, Universitas Islam Agung 2017), 242.

Chusnul Muali, pendidikan akhlak perspektif Al gazali, Ilmu Tarbiyah. vol. 7, no. 2,(At- Tajdid”, Univeritas Nurul Jadid Paiton,2018 ), 197.

Deden Saepul Hidayat. \& Wawan, pendidikan anak berkebutuhan Khusus (tunalaras) Jilid I ( Luxima", Wawan, 2013), 
Desfa Yusmaliana, S. (2019). Pengembangan Imajinasi Kreatif Berbasis Neurosains dalam Pembelajaran Keagamaan Islam. Edukasia: Jurnal Penelitian Pendidikan Islam, 14(2), 267 296. https://doi.org/http://dx.doi.org/10.21043/edukasia.vi4i2.4213

Desy dwi ratnasari, Metode bimbingn akhlak terhadap perlaku anak tunalaras di SLB E Prayuwana Yogyakrta ( UIN", Fakultas Dakwah dan Komunikasi, 2014), xi

Dwi Garnis, studi komprasi pembiasaan akhlak terpuji pada taman kanak-kanak asiyah bustanul athfal 1, studi komprasi, ( PG-PAUD”, Univeritas muhammadiyah Sukabumi, 2017), 43

Fitriah M. Suud, kejujuran dalam prespektif psikologi Islam, psikologi Islam, vol. 4,(PSI", Univeritas Gajah Mada, 2017).

Hasil wawancara kepala sekolah Ernaningsih. Di SLB E Prayuwana Yogyakrta, pada tanggal 30 agustus 2019 pukul 10:00.

Hasil wawancara Trianto, pengampuh PAI. di SLB E Prayuwana Yogyakarta, pada tanggal 25 agustus 2019 pukul 08:00.

Ibrahim Bafadhol, pendidikan akhlak dalam perspektif Islam, Vol. 06 No.12, (PAI”, STAI Al Hidyah Bogor, 2017),57.

Mahamudi, urgensi pendidikan akhlak Ibnu Qayyim," Ta'dibuna, vol. 8, no. 1, (Ta'dibuna", univeritas Islam bandung, 2019),5

Mahmud.,Pemikiran Pendidikan Islam, (UIN”, Sekolah GD, 2011), 21.

Muda menghafal 100 hadist/ Said Yai bin Imanul Huda, Jilid I, (Darus Sunnah", Cet 1, 2016 ), 4.

Muhammad Efendi, pengantar Psikopedagogik Anak Berkelainan, Jilid I, (Bumi Aksara, Cet, 2008, ), 24.

Mentari Marwa, pengetahuan sikap dan keterampilan guru sebagai prevensi terhadap kekerasan seksual pada anak. An-nafs: kajian dan penelitian psikologi vol. 1, ( An_Nafas, IAI Tribakti, 2016).

Maria M Minarsih, pengaruh sikap mandiri, lingkungan keluarga dan motivasi terhadap minat berwirausaha para remaja, of mangement, volume 2,(MFK", Universitas Pandanaran Semarang, 2016), 34.

Najmi Hayati, hubungan penggunaan media pembelajaran audio visual dengan minat peserta didik pada pembelajaran pendidikan agama Islam di SMAN 1 bangkinang Kota, Vol. 14, No. 2,(Al-Hakam“, 2017), 162.

Nur Ainiyah, Pembentukan Karakter melalui Pendidikan Agama Islam, Al-Ulmu volume. $13 \mathrm{Nr}$ 1,(Al- Ulum”, Universitas Negeri Semarang, 2013 ),29

Nur Ainiyah, Pembentukan Karakter melaluiPendidikan Agama Islam, Al-Ulmu volume. $13 \mathrm{Nr}$ 1,(Al- Ulum", Universitas Negeri Semarang, 2013), 36

Rahman Ritonga, Akhlak Merakit Hubungan Denga Sesama, Jilid I, (Surabaya: Amelia Surabaya, 2005) 13-19.

Somantri T. Sutjihati, Psikologi Anak, Jilid II, ( GMD : Refika Aditama ,Cet 1, 2016), 140.

Saifullah, konsep pembentukan karakter siddiq dan amanah pada anak melalui pembiasaan puasa sunat, mudarrisuna volume 7, Nomor 1,(UIN", Ar- Raniry Bnda Aceh, 2017), 91-92.

Suyadi. (2013). Strategi Pembelajaran Pendidikan Karakter. Rosdakarya. https://www.tokobukurahma.com/strategi-pembelajaran-pendidikan-karaktersuyadi/\#.WshAtdRubIU , (2016). Teori Pembelajaran Anak usia Dini Dalam Kajian Neurosains. Remaja Rosdakarya. http://www.bukukita.com/Orang-Tua-dan-Keluarga/Psikologi-\&-Pendidikan-Anak/129444Teori-Pembelajaran-Anak-usia-Dini-Dalam-Kajian-Neurosains.html , (2017). Pendidikan Islam Inklusi Humanis Dan Religius. Tajdidukasi, 7(2), 15-27. https://doi.org/10.31332/am.v9i1.773

, (2018a). Pendidikan Islam Anak Usia Dini Dalam Perspektif Neurosains: Robotik Akademik Dan Saintifik. Edukasia: Jurnal Penelitian Pendidikan Islam, 13(2), 231-262. https://doi.org/http://dx.doi.org/10.21043/edukasia.v13i2.3255 
, (2018b). Rekonstruksi Filsafat Tarbiyah: Telaah Atas Pemikiran Abbas Mahjub.

Tajdidukasi: Jurnal Penelitian Dan Kajian Pendidikan, 8(2).

Suyadi dan Maulidya Ulfa. (2013). Konsep Dasar PAUD. Remaja Rosdakarya.

Suyadi, K. Z. P. \&. (2016). Bimbingan dan Konseling PAUD. Rosda Karya.

Suyadi, S. (2019). Immunology Pedagogical Psychology of Pesantren Kindergarten: Multicase

Study at Pesantren Kindergarten in Yogyakarta. Addin, 13(1), 57. https://doi.org/10.21043/addin.v13i1.3510

, Saifurrahman \&. (2019). Desain Pembelajaran Keagamaan Islam Berbasis Neurosains. AlMurabbi: Jurnal Studi Kependidikan Dan KeIslaman, 6(1), 55-73. http://dx.doi.org/10.1186/s12909-017-0855x\%0Ahttp://dx.doi.org/10.1080/2331186X.2016.1264173

, (2018). The Synergy of Arts, Science, and Islam in Early Childhood Learning in Yogyakarta. Tarbiya: Journal of Education in Muslim Society, 5(1), 30-42. https://doi.org/10.15408/tjems.v5i1.7934

St Daroja, Metode penanaman Akhlak dalam Pembentukan PerilakuSiswa MTs N Ngawen Gunungkidul, Pendidikan Madrasah, Volume 1, Nomor 2, (GMMSY”, Pendidikan Madrash, 2006), 238

Syaepul Manan, pembinaan akhlak mulia melalui ketaladanan dan pembiasaan, Vol. 15 no.No 1,(Ta'lim:, Pendidikan Agama Islam, 2017), 54.

Tiara Rahyu, perilaku anak tunalaras di SLB E ditinjau dari aspek sosial budaya yogakarta, jassi_anakku volume 18 nomor2,(JASSI, Universitas pendidikan indonesia, 2017), 71.

Undang-undang Sistem Pendidikan Nasional, Jilid I, (Bandung: Fokus Media, 2009), 2.

Yanti, Syukri, Hilda, peningkatan kemampuan membedakan perilaku bauk dan buruk PAUD ADINDA MELAWI, ( SPG”, Pendidikan Anak Usia Dini, 2016), 2

Wulandari, A., \& Suyadi, S. (2019). Pengembangan Emosi Positif Dalam Pendikan Islam Perspektif Neurosains. Tadrib: Jurnal Pendidikan Agama Islam, 5(1), 51-67. https://doi.org/10.19109/tadrib.v5i1.3016 